\title{
Grain supplementation on bluestem range for intensive-early stocked steers
}

\author{
CLENTON E. OWENSBY, ROBERT C. COCHRAN, ROBERT T. BRANDT, JR., ERIC S. \\ VANZANT, LISA M. AUEN, AND E.M. CLARY
}

\begin{abstract}
Owensby and Auten are with the Deparment of Agronomy, Kansas State Universin;, Manhattan, 66506-5501; Cochran, Brant and Clary are with the Department of Animal Science and Industry; Kansas State University, Manhattan, 66506; and Vanzant, Ft. Hays Branch Experiment Station, Kansas State University, Hays 67601.
\end{abstract}

\begin{abstract}
A 4-year study was conducted on Kansas Flint Hills bluestem range to monitor animal gain, grass, and forb standing biomass following grazing, plant population dynamics, and in 2 years, subsequent feedlot performance of steers under intensive-early stocking supplemented with increasing levels of sorghum grain. Each year from 1988 through 1991, crossbred beef steers were stocked at $0.24 \mathrm{ha} / 100 \mathrm{~kg}$ of initial steer weight from 5 May to 15 July. Steers in twice-replicated pastures were given no supplementation, $0.91 \mathrm{~kg}$ rolled sorghum grain per head daily, or 1.82 $\mathrm{kg}$ rolled sorghum grain per head daily, which corresponded to approximately $0,0.3$, and $0.6 \%$ of body weight -1 . All steers were implanted with estradiol 17 beta in 1988 and zeranol in 1989-91 during initial processing and had unlimited access to a lasalocid/mineral mixture during the entire trial. In 1989 and 1990, representative groups of steers selected from all treatment/pasture combinations were subjected to a feedlot finishing phase and carcass data were obtained. Grass and forb standing crops were estimated each year at livestock removal in mid-July and again in early October. Pretreatment species composition and basal cover were determined in 1988 and compared to those at the end of the study. In mid-July, when cattle were removed, residual standing biomass of grass increased in direct proportion to increasing level of supplement. Standing biomass of grass at the end of the growing season did not differ among pastures with different supplement levels. Forb standing biomass did not differ among pastures with different supplement levels in July or October. Changes in plant populations among treatments during the course of the study were minimal. During the early portion of the grazing period, sorghum grain supplementation did not significantly influence steer gains, but average daily gain during the latter part of the grazing period increased in direct proportion to increasing level of sorghum grain supplement. Daily gain, feed intake, carcass characteristics, and gain:feed ratio were not different among treatments during the feedlot phase. Although conversion efficiencies may be economically marginal, low-level grain supplementation has the potential to increase the daily gain
\end{abstract}

This article is contribution No. 94-449-J. Kansas Agricultural Experiment Station, Munhattan 66506.

Mánuscript accepted 7 Sept. 1994. of cattle grazing early-season tallgrass prairie under an intensive-early stocking program.

Key Words: grain sorghum, beef cattle, tallgrass prairie, feedlot performance

Intensive-early stocking (Smith and Owensby 1978, Owensby et al. 1988) has become an important livestock grazing system in the Kansas Flint Hills region. Increased per hectare gains without reduced individual animal gains and maintenance or improvement of biomass production and desirable plant populations have been the principal reasons for its acceptance. Furthermore, livestock managed under intensive-early stocking systems in the tallgrass prairie region consume forage at the peak of nutritive value. Feedlot efficiency also has increased for steers following intensive-early stocking (Posler et al. 1985).

When cattle consume low-quality forages, feeding supplements with a low protein to energy ratio (e.g., cereal grains) frequently depresses digestion and may negatively affect voluntary forage intake (Chase and Hibberd 1987, DelCurto et al. 1990). In contrast, feeding relatively low amounts $\left(\leq 0.67 \%\right.$ of body weight $\left.{ }^{-1}\right)$ of similar types of supplements to cattle consuming average- to high-quality tallgrass prairie forage does not appear to negatively impact forage use on Flint Hills range (Vanzant et al. 1990). Thus, one would expect to observe improvement in the daily gain of cattle grazing Flint Hills grasslands under an intensive-early stocking program when they receive grain supplements at a rate of $.67 \%$ body weight ${ }^{-1}$ or less. However, research validating supplementation response by cattle managed under an intensive early stocking grazing program is lacking.

In order to determine the appropriate use of supplementation within intensive-early stocking programs, information describing effects of supplementation on animal performance as well as pasture characteristics is needed. Furthermore, to assess the impact of supplementation on overall system efficiency, it is important to monitor potential effects on livestock performance during the finishing process. We hypothesized that supplemental sorghum grain for intensive-early grazed steers on Kansas bluestem range would not affect biomass production or botanical composition, nor would the increased animal gain from the supplemental sorghum grain affect feedlot gain. To test that hypothesis, we 
conducted a 4-year study to monitor animal gain on pasture, grass, and forb standing crop following grazing, plant population dynamics. and, in 2 years, subsequent feedlot performance for steers under intensive-early stocking and supplemented with increasing levels of sorghum grain.

\section{Materials and Methods}

The study area was the Kansas State University Experimental Range Unit located in the northern Flint Hills near Manhattan, Kan. The warm-season, perennial tallgrasses, big bluestem (Andropogon gerardii Vitman.), and indiangrass (Sorghastrum nutans Nash), were the dominant forage species, and little bluestem (A. scoparius Michx.), and sideoats grama [Bouteloua curtipendula (Michx.) Torr.], both warm-season, perennial midgrasses. were subdominants. Numerous grass, forb, and woody species constituted the remainder. Soils were transitional from Ustolls to Udolls (fine, mixed, mesic, montmorillonitic, Pachic Argiustolls). The principal range sites in the study area were loamy upland, breaks, and clay upland (Anderson and Fly 1955). The study pastures had similar amounts of each of the principal range sites. Precipitation during the study period was below normal in all years, and only in 1990 approached the 30year average (Table 3 ).

Each year from 1988 through 1991, crossbred beef steers (a mixture of British $\times$ British and British $\times$ Zebu) were assigned randomly to six, 24.3-ha pastures. Pastures were stocked at a rate that allowed approximately $0.24 \mathrm{ha} / 100 \mathrm{~kg}$ of initial steer weight. Average initial weights and numbers of steers used were; 1988: $252 \mathrm{~kg}, \mathrm{n}=240 ; 1989: 285 \mathrm{~kg}, \mathrm{n}=210 ; 1990: 268 \mathrm{~kg}, \mathrm{n}=216 ; 1991$ : $238 \mathrm{~kg}, \mathrm{n}=246$. This translated into an average stocking rate of approximately $0.62 \mathrm{ha} / \mathrm{animal}$. Long-term stocking rate studies with the intensive-early stocking system indicate that stocking rates in the range of 0.57 to $0.70 \mathrm{ha} / \mathrm{animal}$ are acceptable for steers with weights similar to those used in this study (Owensby et al. 1988). All pastures were burned each year during the last 10 days of April, and steers were turned onto pastures when approximately 5 to $7.5 \mathrm{~cm}$ of new plant growth had occurred. The average date when steers entered the pastures was 5 May. The average date when steers were removed from the pastures was 15 July.

Steers were identified individually and weighed at the beginning, middle, and end of each grazing period. Steers were weighed in the early morning after being held overnight without access to feed or water. Pastures were assigned randomly to 1 of 3 treatments (2 pastures/treatment): 1) no supplementation; 2) $0.91 \mathrm{~kg}$ rolled sorghum grain per head daily; 3 ) $1.82 \mathrm{~kg}$ rolled sorghum grain per head daily on an as fed basis. The sorghum grain averaged $92 \%$ dry matter and $11 \%$ crude protein. Given the average starting weight of the steers and average weight gain, the supplementation rates corresponded to approximately $0,0.3$, and $0.6 \%$ of body weight ${ }^{-1}$. Pasture treatments were the same throughout the 4 years of the experiment. Supplemented groups were bunk-fed daily at approximately 1300-1400 hours. All steers were implanted with estradiol 17 beta in 1988 and zeranol in 1989-91 during initial processing and had unlimited access to a lasalocid/mineral mixture during each year of the experiment. Consumption of that mixture was not different $(P>0.10)$ among treatments and averaged $77 \mathrm{~g} /$ day (approximately $125 \mathrm{mg}$ lasalocid/head daily). The efficiency with which additional gain was achieved in response to supplementation was calculated by dividing the amount of gain above that attained by the unsupplemented steers by the quantity of supplement fed. Following the grazing phase in 1989 and 1990. a representative group of steers selected from all treatment/pasture combinations ( $\mathrm{n}=192$ in $1989, \mathrm{n}=$ 144 in 1990) were subjected to a finishing phase to measure the effects of supplementation on subsequent finishing performance. In each year, rolled corn served as the base concentrate in the finishing diet with corn silage constituting $10 \%$ of the diet dry matter. Diets were formulated to contain $12 \% \mathrm{CP}, .7 \% \mathrm{Ca}, .35 \% \mathrm{P}$, $.7 \% \mathrm{~K}$, and $2200 \mathrm{IU}$ of vitamin $\mathrm{A} / \mathrm{kg}$ dry matter. Diets were fortified with trace minerals and salt. Steers were implanted with estradiol benzoate at the initiation of the finishing phase. The finishing phases lasted 116 days in 1989 and 108 days in 1990. Immediately following recording of the final weights, steers were shipped to a nearby slaughter facility and slaughtered upon receipt. Carcass data were obtained by trained personnel following a 24-hour chill.

Grass and forb standing crops were estimated each year at livestock removal in mid July and again in early October by clipping ten, $0.5-\mathrm{m}^{2}$ plots to ground level in both loamy upland and breaks range sites. October standing crop estimates were to determine regrowth differences among treatments. Clipped samples were dried until moisture-free and then weighed. Species composition was determined from basal cover estimates (percent of ground covered by plant bases) using the modified step-point method (Owensby 1973). Pastures were sampled annually during the first half of June. Within each pasture, 1,500 points were read along a predetermined grid. Each point was recorded as to range site. Pretreatment species composition and basal cover were determined in 1988, and analysis of variance was conducted on the arc sine-transformed difference between pretreatment percentages and those at the end of the study.

Plant standing biomass data were analyzed as a randomized complete block using SAS-ANOVA (SAS 1988) with pasture, supplementation rate, range site, and year as the variables. The sums of squares for supplementation rate were partitioned into linear and quadratic effects of sorghum grain level with orthogonal polynomials. Plant census data were analyzed similarly except year was not in the model and means were separated using least significant difference $(P \leq 0.10)$. Steer data (from the grazing and finishing phases) were analyzed using the SAS GLM procedure (SAS 1988) with pasture, supplementation rate, and year as the variables. Each pasture group was used as a block in the feedlot trial and all treatments were represented within each block. There were multiple pens available for each treatment within each pasture group. Because steers were group-fed by pasture and pen during the grazing and finishing phases, respectively, pasture group and feedlot pen were considered to be the experimental units. The sums of squares for supplementation rate were partitioned into linear and quadratic effects of sorghum grain level with orthogonal polynomials.

\section{Results}

\section{Standing Biomass}

Standing biomass response to different supplement levels was consistent among years and across range sites (e.g., no interactions among supplement level, range site, and years were statistically significant, $P=0.29$ ). In mid-July, when the cattle were 


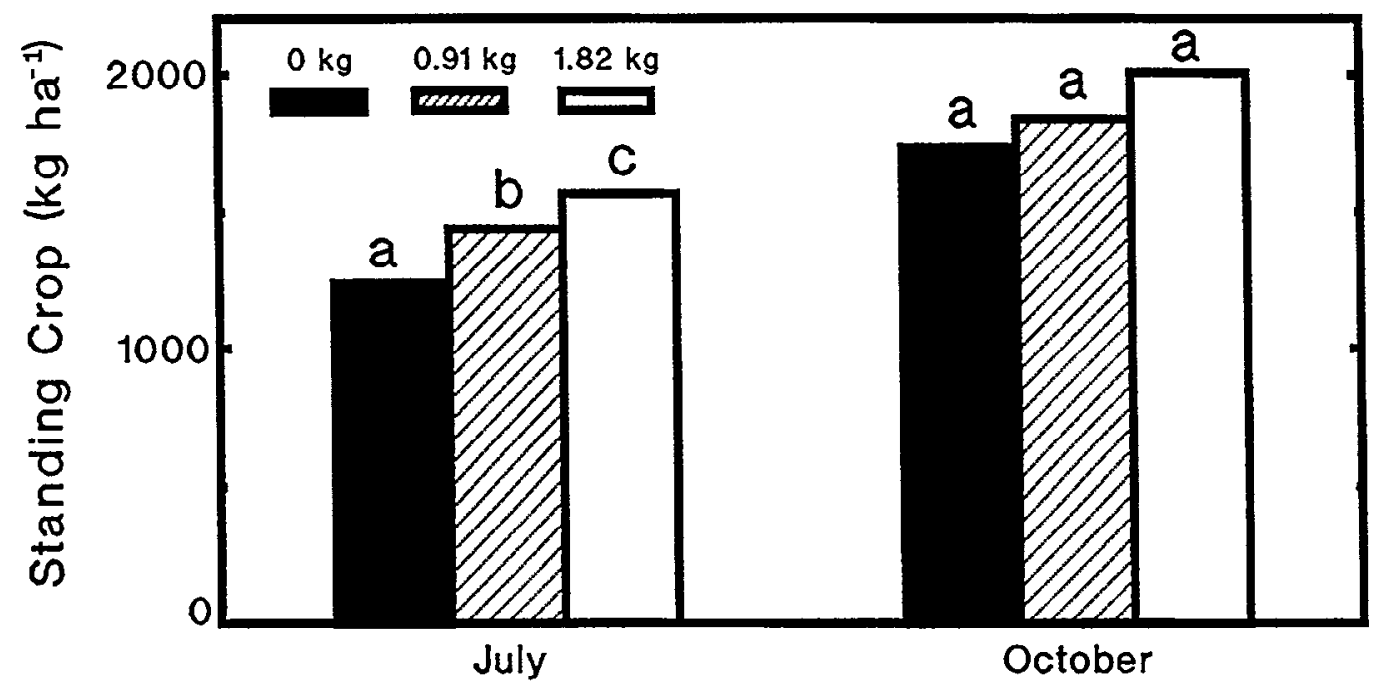

Fig. 1. Standing crop of biomass remaining in mid July and early October on pastures stocked from 5 May to 15 July each year from 1988 through 1991 with yearling steers that received no supplement or a daily supplement of 0.9 or $1.8 \mathrm{~kg}$ rolled sorghum grain per steer. Means with a common letter do not differ (July -linear, $P=0.001$; October - linear, $P=0.12$ )

removed, biomass remaining increased linearly $(P=0.001)$ in direct proportion to increasing level of supplement (Fig. 1). Standing biomass of grass at the end of the growing season tended to increase linearly $(P=0.12)$ with increasing level of supplement. Forb standing biomass did not differ among pastures with different supplement levels in July ( $P=0.62)$ or October $(P=0.86)$.

\section{Plant Census}

Changes in plant populations among treatments during the course of the study were minimal. No significant change occurred in percent composition or percent basal cover of the dominant warm-season perennial grasses or forbs, but relative composition of $A$. scoparius was lower on all pastures. The reduction was greater $(P=0.067)$ on pastures supplemented with $1.8 \mathrm{~kg}^{-1}$ grain than on those with $0.9 \mathrm{~kg}^{-1}$ or unsupplemented (Fig. 2). Over the 4-year period, $P$. pratensis increased $(P=0.062)$ on unsupplemented pastures and those with $0.9 \mathrm{~kg}^{-1}$ supplement, but decreased slightly on pastures supplemented with $1.8 \mathrm{~kg}^{-1}$.

\section{Animal Performance}

The total amount gained by steers in all treatment groups differed among years $(P \leq 0.01)$; however, response to supplementa-

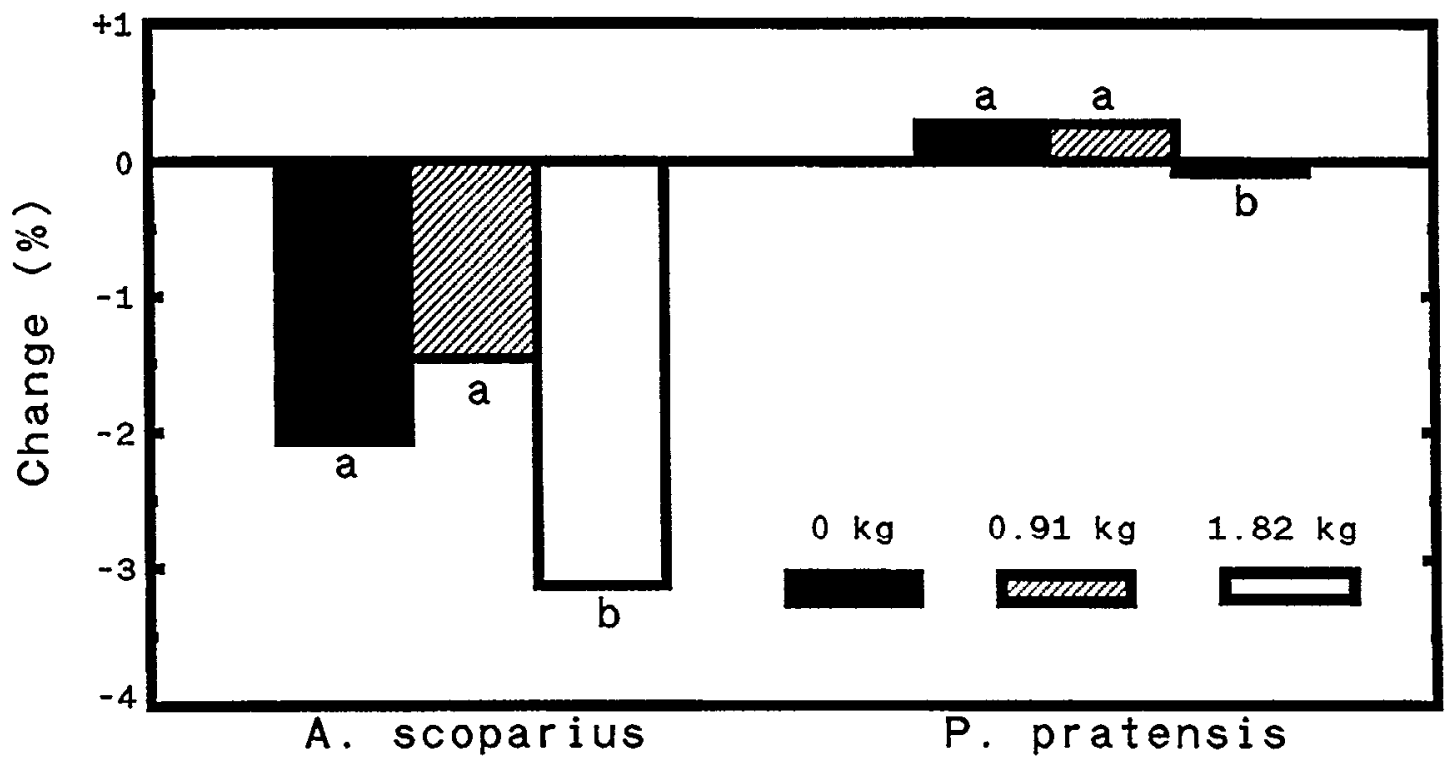

Fig. 2. Change in botanical composition over the 4-year study period for indicated plant species on pastures stocked from 5 May to 15 July each year from 1988 through 1991 with yearling steers that received no supplement or a daily supplement of 0.9 or $1.8 \mathrm{~kg}$ rolled sorghum grain per steer. Means (averaged over 2 range sites) with a common letter do not differ $(P<0.10)$. 
Table 1. Influence of Ievel of grain supplementation on average daily gain of yearling steers on pastures stoched from 5 May to 15 July each year from 1988 through 1991.

\begin{tabular}{|c|c|c|c|c|c|c|}
\hline \multirow[b]{2}{*}{ Item } & \multicolumn{4}{|c|}{ Supplement Level, kg day ${ }^{-1}$} & \multicolumn{2}{|c|}{ Prohability Level } \\
\hline & 0.00 & 0.91 & 182 & SEM & Linear & Quadratic \\
\hline \multicolumn{7}{|c|}{ Average daily gann. $\mathrm{kg}$ day ${ }^{-1}$} \\
\hline May to early-June & 1.13 & 1.18 & 127 & 0.19 & 0.33 & 0.90 \\
\hline Early-June to Mid-July & 0.86 & 1.02 & 1.08 & 0.12 & 0.07 & 0.53 \\
\hline May to Midd-July & 1.00 & 1.10 & 1.18 & 0.15 & 0.16 & 0.86 \\
\hline
\end{tabular}

tion was consistent throughout the 4 years of the experiment. During the early portion of the grazing period (May-Early June). sorghum grain supplementation did not influence steer gains $(P \leq 0.05)$ (Table 1$)$. In contrast, average daily gain during the latter part of the grazing period (early-June to mid-July) increased in direct proportion to increasing level of supplement (linear, $P$ $=0.07$ ). Response to supplementation over the entire grazing period displayed a similar trend $(P=0.16)$. The additional units of gain attained (above the controls) per unit of supplement fed were relatively similar for the 2 supplementation rates $(0.12$ for the $0.91 \mathrm{~kg}^{-1}$ treatment and 0.10 for the $1.82 \mathrm{~kg}^{-1}$ treatment). This equates to feeding $S$ to 10 units of grain for each additional unit of gain above the control group.

Daily gain, feed intake, and gain:feed ratio were not different among treatments during the finishing phase (Table 2). Furthermore, the trend (linear, $P=0.11$ ) for treatment groups to differ in initial feedlot weight tended to be present at the end of the finishing period (linear, $P=0.16$ ). Hot carcass weight increased linearly $(P=0.07)$ with increasing level of grain supplementation during the pasture phase. Dressing percentage tended to change in a quadratic $(P=0.07)$ fashion with increasing supplementation rate. Carcass quality characteristics did not differ among treatments $(P>0.10)$.

\section{Discussion}

The linear increase in the amount of standing biomass remaining at the end of the grazing period with increasing supplement rate suggests that forage intake declined in proportion to the increase in the amount of grain supplement consumed. Horn and McCollum (1987) reviewed research in which "energy" supple-

Table 2. Influence of grain level during the grazing period on subsequent feedlot performance and carcass characteristics of yearling steers from pastures stockcd from 5 May to $15 \mathrm{July}$ in 1988 and 1990.

\begin{tabular}{|c|c|c|c|c|c|c|}
\hline \multirow[b]{2}{*}{ Item } & \multicolumn{4}{|c|}{ Supplement Level, $\mathrm{kg} \mathrm{day}^{-1}$} & \multicolumn{2}{|c|}{ Probability Level } \\
\hline & 0.00 & 0.91 & 1.82 & SEM & Linear & Quadratic \\
\hline Initial Weight (kg) & 354 & 361 & 366 & 4.50 & 0.11 & 0.88 \\
\hline Final Weight (hg) & 532 & 540 & 542 & 4.50 & 0.16 & 0.55 \\
\hline $\begin{array}{l}\text { Dry Matter Intake } \\
\left(\text { (l.g day } y^{-1}\right)\end{array}$ & 10.10 & 10.20 & 10.20 & 0.09 & 0.87 & 0.51 \\
\hline $\begin{array}{l}\text { Average Daily Gain } \\
\left(\mathrm{kg} \text { day }{ }^{-1}\right)\end{array}$ & 1.58 & 1.59 & 1.56 & 0.03 & 0.68 & 0.53 \\
\hline $\begin{array}{l}\text { Gain:Feed Ratio } \\
\left(\mathrm{kg} \mathrm{kg}^{-1}\right)\end{array}$ & 0.16 & 0.16 & 0.15 & 0.00 & 0.61 & 0.89 \\
\hline Hot Carcass Weight) $(\mathrm{kg})$ & 327 & 332 & 334 & 2.70 & 0.07 & 0.70 \\
\hline Dressing Percentage & 64.10 & 63.80 & 64.60 & 0.20 & 0.07 & 0.07 \\
\hline Yicld Grade & 3.00 & 3.05 & 2.99 & 0.09 & 0.95 & 0.61 \\
\hline Marblingid & $\operatorname{Sm} 27$ & $\operatorname{Sm} 33$ & $\mathrm{Sm} 20$ & 0.09 & 0.61 & 0.40 \\
\hline
\end{tabular}

$4 \mathrm{Sm}=\mathrm{small}: \mathrm{sm0}$ to $\mathrm{sm} 100=$ low choice. ments (e.g., cereal grains) were fed to cattle consuming forages and concluded that large effects on forage intake would not be expected unless supplement consumption exceeded $30 \mathrm{~g} / \mathrm{kg}$ body weight ${ }^{75}$. However, Horn and McCollum (1987) also noted that substitution ratios generally increase as digestibility of the basal forage in the diet increases. Results reported by Vanzant et al. (1990) conform to the proposed threshold of $30 \mathrm{~g} / \mathrm{kg}$ body weight ${ }^{75}$ in that steers fed early-season bluestem up to $28 \mathrm{~g} / \mathrm{kg}$ body weight ${ }^{75}$ of sorghum grain did not have a decrease in forage intake. Although the highest level of supplement offered in our study (approximately $28 \mathrm{~g} / \mathrm{kg}$ body weight ${ }^{75}$ ) was similar to that used by Vanzant et al. (1990), forage intake appears to have been depressed in proportion to increasing supplementation. One possible explanation for the apparent difference between these trials may be the quality of the forage consumed. Although the forage fed by Vanzant et al. (1990) was harvested in the early summer, it is highly likely that steers grazing similar pastures would select a diet of higher quality. In light of Horn and McCollum's (1987) observation that substitution rates become larger with increasing forage digestibility, increased quality in the forage consumed may translate into a greater likelihood of forage intake being affected by supplementation. Other studies in which "energy" supplements have been fed to cattle grazing average- to high-quality forages have reported depressions in forage intake at relatively low rates of supplementation. For example, Pordomingo et al. (1991) noted a decrease in the intake of summer-grazed blue grama range when the level of supplemental corn exceeded approximately $9.5 \mathrm{~g} / \mathrm{kg}$ body weight .75 (approximately $0.2 \%$ body weight). Similarly, Adams (1985) reported a decrease in the consumption of fall-grazed Russian wild ryegrass for steers supplemented with corn at a rate of approximately 12.4 $\mathrm{g} / \mathrm{kg}$ body weight ${ }^{75}$.

The forage growth that occurred between mid July and October was apparently greater on pastures with lower amounts of standing biomass remaining in mid July, because no differences occurred in standing biomass in October among treatments. The lower herbivory on pastures as supplement rate increased, represented by a greater standing biomass remaining in mid July, may have increased water use because of greater transpirational tissue, thereby providing less water for late-season growth. Precipitation during the study period was below normal in all years, and only in 1990 approached the 30-year average (Table 3). Because there were small diffirences in standing biomass among pastures with different supplement levels when livestock were removed in July and no difference occurred among treatments at the end of the growing season in October, the minimal change in botanical composition is not surprising.

The rate of gain for the unsupplemented steers during the pasture phase of this experiment was similar to that reported by Owensby et al. (1988) for steers grazing similar pasture and managed under the intensive-early stocking program. The trend for increased daily gain with increasing supplementation concurs with a report of increased digestible energy intake by steers receiving early-season bluestem and increasing amounts of sorghum grain (Vanzant et al. 1990). Although daily gain during the pasture phase tended to respond positively to supplementation, the conversion efficiency was economically marginal for both supplementation treatments. If forage intake was affected negatively by supplementation, this would lessen potential treatment differences in digestible energy intake. An effect of this type could influence conversion efficiency. In addition, changes 
Table 3. Monthly precipitation ( $\mathrm{mm})$ and deviation from normal for the study site.

\begin{tabular}{|c|c|c|c|c|c|c|c|c|}
\hline \multirow[t]{2}{*}{ Yeur } & \multicolumn{2}{|c|}{1988} & \multicolumn{2}{|c|}{1989} & \multicolumn{2}{|c|}{1990} & \multicolumn{2}{|c|}{1991} \\
\hline & Ppt. & Dev. & Ppt. & Dev. & Ppt. & Dev. & Ppt. & Dev. \\
\hline Month & \multicolumn{2}{|c|}{$(\mathrm{mm})$} & \multicolumn{2}{|c|}{$(\mathrm{mm})$} & \multicolumn{2}{|c|}{$(\mathrm{mm})$} & \multicolumn{2}{|c|}{$(\mathrm{mm})$} \\
\hline Jan & 8 & -13 & 0 & -21 & 27 & 6 & 34 & 13 \\
\hline Feb & 13 & $-I I$ & 0 & -24 & 22 & -2 & 1 & -23 \\
\hline Mar & 13 & -40 & 6 & -46 & 105 & 52 & 35 & -18 \\
\hline Apr & 81 & 10 & 8 & -62 & 23 & -48 & 107 & 36 \\
\hline May & 58 & -57 & 40 & -74 & 100 & -14 & 130 & 16 \\
\hline Jun & 91 & -43 & 74 & .60 & 124 & -10 & 51 & -83 \\
\hline Jul & 97 & -4 & 30 & .71 & 79 & -22 & 47 & -54 \\
\hline Alug & 60 & -20 & 141 & 60 & 180 & 100 & 56 & -25 \\
\hline Sep & 47 & -55 & 175 & 72 & 20 & -83 & 44 & -59 \\
\hline Oet & 14 & -59 & 143 & 70 & 27 & -46 & 33 & -40 \\
\hline Nov & 25 & -12 & 0 & -37 & 52 & 14 & 83 & 46 \\
\hline Dec & 6 & -17 & 2 & -21 & 26 & 3 & 48 & 25 \\
\hline Total & 513 & -322 & 619 & -214 & 785 & -50 & 669 & -166 \\
\hline
\end{tabular}

in digestibility also may have contributed somewhat to the marginal conversion efficiencies, in that Vanzant et al. (1990) reported small, but significant, depressions in total diet dry matter digestion with increasing supplementation of similar diets. No compensatory growth was observed in the finishing period, regardless of supplementation treatment during the pasture phase. Similar results were reported by Lake et al. (1974) for steers grazing irrigated cool-season grass pastures and supplemented with up to $1.82 \mathrm{~kg}$ of corn daily. Moderate levels of nutritional restriction have resulted in compensatory growth in subsequent high-grain feeding phases for beef calves (Brandt et al. 1989) and Holstein steers (Unpublished data, Reinhardt, C.D.. and R.T. Brandt). However, the relatively small differences in pasture gains among treatments may have precluded expression of a compensatory growth response in this study.

\section{Conclusions}

Although conversion efficiencies may he marginal, low-level grain supplementation has the potential to increase the daily gain of cattle grazing early-season tallgrass prairie under an intensiveearly stocking program. Provision of grain supplements to cattle consuming relatively high-quality forage may result in substitution of grain for forage intake. However, little effect would be expected on the botanical composition of pastures in which cattle receive low-level supplementation. The level of gain promoted by low-level grain supplementation of steers on early-season pasture is unlikely to negatively affect subsequent feedlot performance.

\section{Literature Cited}

Anderson, K.L., and C.L. Fly. 1955. Vegetation-soil relationships in flint hills bluestem pastures. J. Range Manage. 8:163-169.

Adams, D.C. 1985. Effect of time of supplementation on performance, forage intake, and grazing behavior of yearling beef steers grazing Russian wild ryegrass in the fall. J. Anim. Sci. 61:1037-10+2..

Brandt, Jr., R.T., S.J. Anderson, J.K. Elliott, and J.R. Brethour. 1989. Growing-finishing systems for medium-framed steer calves. J. Anim. Sci. 67(Suppl. 1):569.

Chase, C.C., and C.A. Hibberd. 1987. Utilization of low-quality native grass hay by beef cows fed increasing amounts of com grain. J. Anim. Sci. 65:557-566.

DelCurto, T., R.C. Cochran, D.L. Harmon, A.A. Beharka, K.A. Jacques, G. Towne, and E.S. Vanzant. 1990. Supplementation of dormant tallgrass-prairie forage: $\mathbb{I}$. Influence of varying supplemental protein and(or) energy levels on forage utilization characteristics of beef steers in confinement. J. Anim. Sci. 68:515-531.

Horn, G.W. and F.T. McCollum. 1987. Energy supplementation of grazing ruminants, p. 125-136. In: Proc. Grazing Livestock Nutrition Conference. University of Wyoming, Laramie, Wyo.

Lake, R.P., R.L. Hildebrand, D.C. Clanton, and L.E. Jones. 1974. Limited energy supplementation of yearling steers grazing irrigated pasture and subsequent feedlot performance. J. Anim. Sci. 39:827-833.

Owensby, C.E. 1973. Modified step-point system for botanical composition and basal cover estimates. J. Range Manage. 26:302-303.

Owensby, C.E., R.C. Cochran, and E.F. Smith. 1988. Stocking rate effects on intensive-early stocked Flint Hills bluestem range. J. Range Manage. 41:485-489.

Pordomingo, A.J., J.D. Wallace, A.S. Freeman, and M.L. Galyean. 1991. Supplemental corn grain for steers grazing native rangeland during summer. J. Anim. Sci. 69:1678-1687.

Posler, G.L., G.M. Ward, J.G. Riley, C.E. Owensby, E.F. Smith, K.K. Bolsen, R.M. Helsel, and N.S. Hill. 1985. Alternatives for managing beef yearlings after intensive-early stocking of Kansas Flint Hills range. Proc. XVth Int. Grassland Cong. Kyoto, Japan. Aug. 24-31, 1985.

SAS. 1988. SAS/STAT User's Guide (Release 6.03). SAS Inst., Inc., Cary, N.C.

Snith, E.F. and C.E. Ow ensby. 1978. Intensive-early stocking and season-long stocking of Flint Hills bluestem range. J. Range Manage. 31:14-18.

Vanzant, E.S., R.C. Cochran, K.A. Jacques, A.A. Beharka, T. DelCurto, and T.B. Avery. 1990. Influence of level of supplementation and type of grain in supplements on intake and utilization of harvested, early-growing-season, bluestem range forage by beef steers. J. Anim. Sci. 68:1457-1468. 